\title{
Shorea Leprosula: Most Commercial Trees to Improve Forest Productivity in Low Land Tropical Forest
}

\section{Wahyudi}

Department of Forestry, University of Palangka Raya, Palangka Raya, Central Kalimantan, Indonesia, wahyudi@for.upr.ac.id

Abstract
Deforestation rate in Indonesia was 1,8 million ha per year.
One of causes it was low productivity of production natural
forest: just $0,25 \mathrm{~m} 3$ ha-1 year-1 only (compared with teak
plantation forest productivity in Jawa island: $8-10 \mathrm{~m} 3$ ha-1
year-1). Natural regeneration and forest plantation were
constrained by stand competition and limited of light in the
forest floor. Efforts to improve production natural forest Journal of Business
productivity was applying the Selective Cutting and Strip Management and
Planting (SCSP) system. This system has been had optimum Economic Research
open area (strip) which suitable to maximum growth of Vol.2, Issue.1, 2018
Dipterocarp species, especially Shorea spp as most pp. 9-14
commercial trees in the natural tropical forest. This research
aimed to analyze and created modeling of growth and yield Doi: 10.29226/TR1001.2018.6
of Shorea leprosula plantation in the SCSP system. The research was conducted on research plots of SCSP in logged over - production natural forest of PT Gunung Meranti forest concession, Central Kalimantan Province, Indonesia. Analysis of data used growth modelling for even-aged forest. The result showed that mean annual increment of Shorea leprosula plantation at 2, 11 and 16 year old were 1,06 $\mathrm{cm}$ year-1; 1,22 cm year-1 and 1,31 cm year-1 in diameters, respectively. Based on even-aged forest modelling, the first cycles of Shorea leprosula plantations was 32 year in the $125,14 \mathrm{~m} 3 \mathrm{ha}-1$ of logs (40 $\mathrm{cm}$ up of diameters), thereby Shorea leprosula plantations in the SCSP system could improve the natural forest productivity until 262,72 time. The SCSP system with planted Shorea leprosula is very applicable to apply in the logged over-production natural forest to improve forest productivity.

Keywords: Selective cutting and strip planting system, Shorea leprosula, growth and yield, productivity.

Suggested Citation: Wahyudi (2018), Shorea Leprosula: Most Commercial Trees to Improve Forest Productivity in Low Land Tropical Forest, Journal of Business Management and Economic Research, Vol.2, Issue.1, pp.9-14 


\section{Introduction}

Indonesia is third in the world only Brasilia and Zaire in wide of tropical forest regions and have highest biodiversity too (Whitmore, 1975; Mac Kinnon, et al., 2000). However, the condition of natural forest resources in Indonesia tends to degradate in the quality and quantity along with changed environmental at level of national and also global (Ministry of Forestry, 2008). Deforestation and degraded forest in Indonesia are caused by increasing of resident and wood requirement (Singh, et al. 1995), illegal logging, shifting cultivation, illegal minning, illegal occupation of land, forest fire (Indrawan, 2008), conversion of forest (Saharjo, 2008), and poor forest management (Wahjono and Anwar, 2008).

As comparison, in the year 1990's, logs production in Indonesia are 28 million $\mathrm{m}^{3}$ coming from 59,6 million ha of production forest. But in the year 2007, logs production decrease become 9,1 million $\mathrm{m}^{3}$ from 27,8 million ha of production forest only. Deforestation and degraded forest won't be stoped happened if there isn't repair of production forest management system in Indonesia. Some researches of silvicultural system in Indonesia have been conducted since year of 1993 and applying of Selective Cutting and Strips Planting (SCSP) silvicultural system with intensively silvicultural technique has done limited to 25 of forest concessions since year 2005, using species of Dipterocarp specially Shorea spp. Shorea leprosula is one of Dipterocarp species that recommended to develop in strips area in SCSP system. Afterwards, research on influencing of gap size and slope to increase growth and yield of Shorea spp plantation in the SCSP system is very needed to support this system.

Pursuant to the forest function, forest regions in Indonesia are divided into three regions i.e. conservation forest, protection forest and production forest. Production forest can be divided into some forest region, in the form of virgin forest, logged over forest, low potential forest, bushes-scrub, grassland and critical land. Logged over forest and low potential forest can be managed by Selected Cutting and Strips Planting silvicultural system using Shorea spp, especially Shorea leprosula.

This Research aimed to compile growth and yield modelling of Shorea leprosula that is developed in the strips area. Research was expected can be used by stakeholder, specially for user of SCSP system

\section{Method}

Research was executed in the Permanent Sample Plots of Selective Cutting and Strips Planting in the District of Mandau Talawang, Central Kalimantan Province that planted at 2015 (age of 2 years), 2006 (age of 11 years), and 2001 (age of 16 years). Data was collected at 2017. 
Measured parameters were $\mathrm{dbh}$ and high of Shorea leprosula at the moment of aged 2 years, 11 years, and 16 years. Growth and yield of Shorea leprosula pattern was formed pursuant to the increment and time (years) functions through polinomial equational (Brown, 1997; Burkhart, 2003) that was:

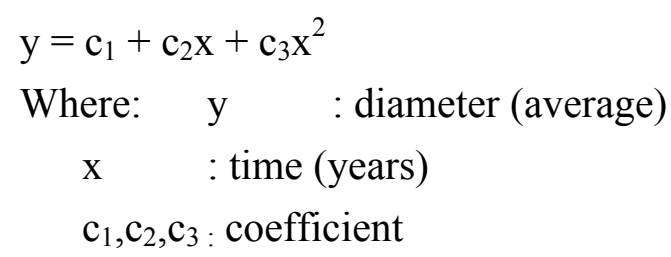

\section{Result and Discussion}

The research result data of Shorea leprosula plantation in the Permanent Sample Plots of Selective Cutting and Strips Planting system that aged of 2 years old, aged of 11 years old, and aged of 16 years old whict collected at 2017 were showed in Table 1.

Tabel 1. Mean annual increment of Shorea leprosula in the PSP of SCSP at 2, 11 , and 16 years old

\begin{tabular}{|c|c|c|c|}
\hline \multirow{2}{*}{$\begin{array}{c}\text { Age } \\
(\text { year })\end{array}$} & \multirow{2}{*}{$\begin{array}{c}|c| \\
(\%)\end{array}$} & \multicolumn{2}{|c|}{ MAl } \\
\cline { 3 - 4 } & $1 \% 0$ & Diameter $(\mathrm{cm})$ & High $(\mathrm{m})$ \\
\hline 0 & 100 & 0 & 0 \\
\hline 2 & 84.22 & 1.06 & 1.4 \\
\hline 11 & 61.87 & 1.22 & 0.94 \\
\hline 16 & 61.21 & 1.31 & 0.82 \\
\hline
\end{tabular}

Table 1 showed that diameter mean annual increment (MAI) of Shorea leprosula since first time until 16 years old always inreasing. MAI of Shorea leprosula was 1,36 cm/tahun at 16 years old with $61,21 \%$ of live . At the 16 years old, diameter and high of Shorea leprosula plantation were 21,22 cm and 13,1 m respectively. Growth and yield of Shorea leprosula always increasing until it achieve 30 to $40 \mathrm{~cm}$ of its diameters (Wahyudi et.al. 2011).

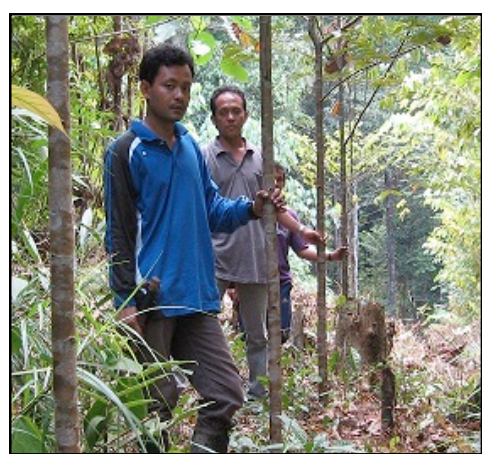

A

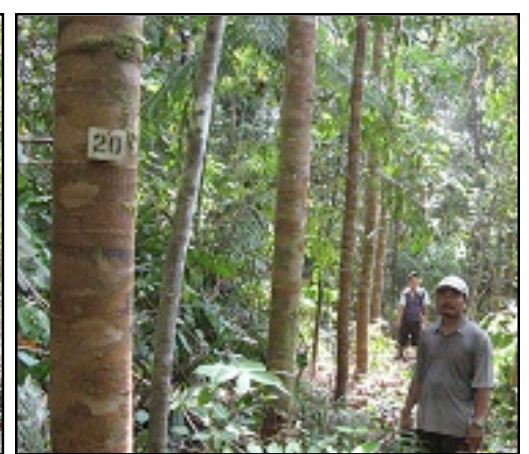

B

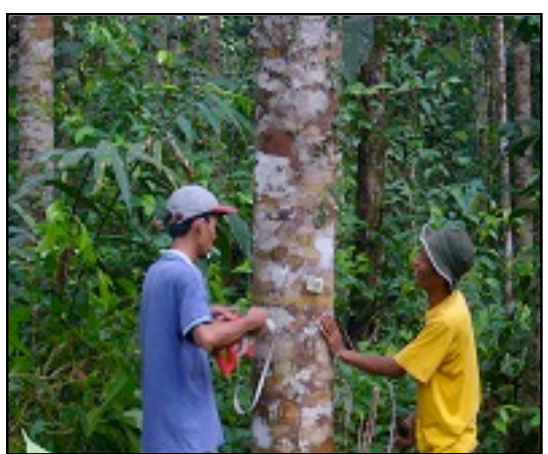

$\mathrm{C}$

Fig.1. Shorea leprosula plantation in the Selective Cutting and Strips Planting system at 2 years old (A), 11 years old (B) and 16 years old (C) 
Growth and yield of trees in the even-aged stand forest different with uneven-aged stand forets. Modelling must considered variation coeffisien and deviation standard of data. There are phenomena in the field that some plants in the monocultural plantation indicate differentation of growth level in each species. There are some species which are very fast, fast, slow and very slow in their growing. This phenomena surmounted through tending and thinning periodically.

Growing of plant can be assumed by as time function. Diameter of plant will be big progressively, but periodically growth must be mentioned in the model, so it needed the time series data to create modelling of growth and yield. Therefore, sigmoid curve to draw the growth of yield of Shorea leprosula also needed the time series data. Modelling must accommodate all information about species, environment, tending, increment and so on. which was made available and trustworthy of growht and yield to create the modelling that can be justified (Grant et al. 1997; Porte \& Bartelink 2001; Vanclay 2001). Pemodelan dapat memudahkan perhitungan yang rumit yang disusun oleh beberapa persamaan dalam waktu bersamaan dengan berbagai simulasi yang kita kehendaki.

Modelling with using polynomial equation based on increment of Shorea leprosula and time funcyions (Brown 1997; Burkhart 2003) as the following:

$\mathrm{Y}=0,0297 \mathrm{x}^{2}+0,8208 \mathrm{x}+0,3728$ $\mathrm{R}^{2}=86,89 \%$

dimana $\mathrm{y}$ : diameter akhir; $\mathrm{x}$ : waktu dalam tahun.

This model predicted that to achieve $50 \mathrm{~cm}$ up of diameter average, needed the time during 32 years as showed in Figure 2. Correlation coeffisient $\left(R^{2}\right)$ of this equations was $86,89 \%$, accordingly, it indicated that this equation can be used to predict growth and yield of Shorea leprosula plantation on the Selective Cutting and Strips Planting system. 


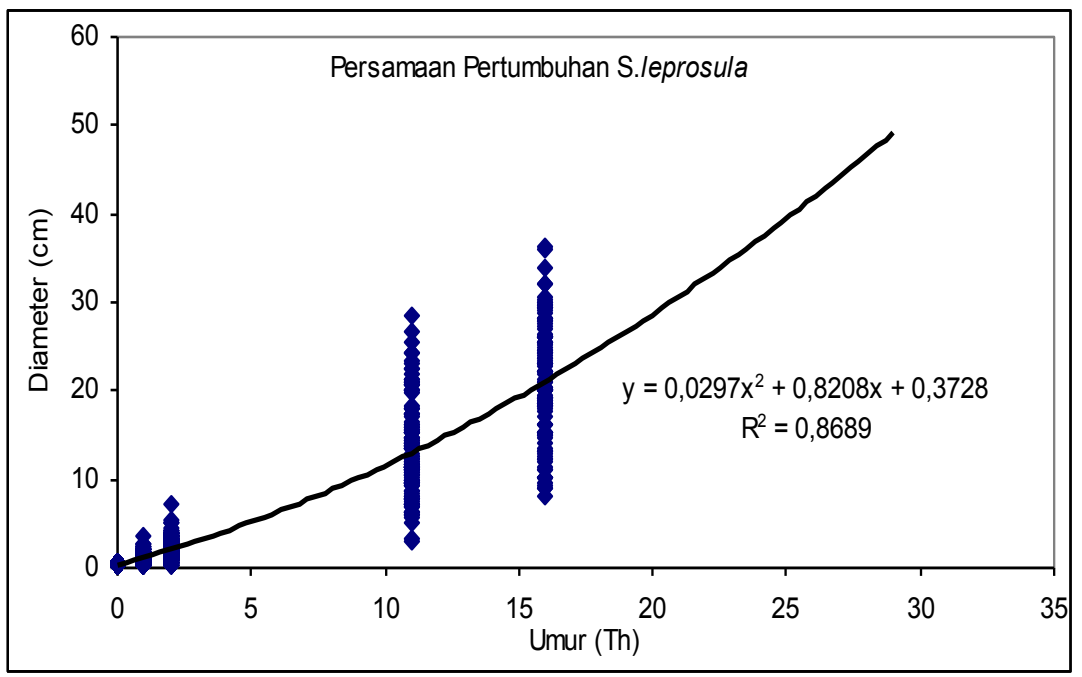

Fig. 2. Growth and Yeld of Shorea leprosula plantation using modelling of polynomial equation

Mean production of logs in PT Gunung Meranti (forest concessionaries) as long as 4 years (2007 to 2010 ) was $22,3 \mathrm{~m}^{3} \mathrm{ha}^{-1}$ of logs. Whereas, based on even-aged forest modelling, the first cycles of Shorea leprosula plantations was 32 years in the $125,14 \mathrm{~m}^{3} \mathrm{ha}^{-1}$ of logs (40 $\mathrm{cm}$ up of diameters), thereby Shorea leprosula plantations in the SCSP system could improve the natural forest productivity until 262,72 time. The SCSP system with planted Shorea leprosula is very applicable to apply in the logged over-production natural forest to improve forest productivity. So, Shorea leprosula is most commercial trees to improve "Production Natural Forest" productivity in the tropical forest.

\section{Conclusion}

Shorea leprosula plantation in the Selective Cutting and Strips Planting silvicultural system can to improve Production Natural Forest productivity in the tropical low land forest start from $0,25 \mathrm{~m}^{3} \mathrm{ha}^{-1}$ to $125,14 \mathrm{~m}^{3} \mathrm{ha}^{-1}$ of logs in the 32 years of cutting cycles.

\section{References}

Brown S. 1997. Estimating biomass change of tropical forest a primer. FAO Forestry Paper No.134. FAO USA.

Burkhart HE. 2003. Suggestion for choosing an appropriate level for modelling forest stand. In Amaro A, Reed D, Soares P, editors. Modelling Forest System. CABI Publishing. 
Coates KD, Philip JB. 1997. A gap-based approach for development of silvicultural system to address ecosystem management objectives. Journal Forest Ecology and Management 99 (1997) 337-35.

Finkeldey R. 1989. An Introduction to Tropical Forest Genetic. Institute of Forest Genetics and Forest Tree Breeding, Goettingen, Germany.

Fyllas NM, Politi PI, Galanidis A, Dimitrakopoulo PG, Arianoutsou M. 2010. Simulating regeneration and vegetation dynamics in Mediterranean Coniferous Forest. Ecology Modelling Journal. 34.

Gadow KV, Hui G. 1999. Modelling Forest Development. Kluwer Academic Publishers.

Grant WE, Pedersen EK, Marin SL. 1997. Ecology and Natural Resource Management. Systems Analysis and Simulation. John Wiley \& Sons, Inc.

Kozlowski TT, Pallardy SG. 1997. Physiology of Woody Plants. Academic Press.

Porte A, Bartelink HH. 2001. Modelling mixed forest growth: a review of models for forest management. Eco. Model. Journal.

Radonsa PJ, Koprivica MJ, Lavadinovic VS. 2003. Modelling current annual height increment of young Douglas-fir stands at different site. In Amaro A, Reed D, Soares P, editors. Modelling Forest System. CABI Publishing.

Rodriguez F, De La Rosa JA, Aunos A. 2003. Modelling the diameter at breast height growht of Populus euramericana plantation timber in Spain. In Amaro A, Reed D, Soares P, editors. Modelling Forest System. CABI Publishing.

Vanclay JK. 2001. Modelling Forest Growth and Yield. Applications to Mixed Tropical Forest. CABI Publishing.

Wahyudi. 2009. Selective cutting and line enrichment planting silvicultural system development on Indonesian tropical rain forest. In: GAFORNInternational Summer School, Geor-August Universität Göttingen and Universität Dresden, Germany.

Wahyudi, Indrawan, Mansur, and Pamoengkas. 2011. Growth and Yield of Plantation and Residual Trees in the Intensified Indonesian Selective Cutting and Strips Planting System. Case Study on Kapuas District, Central Kalimantan Province. Post-Graduate Program - Bogor Agricultural University, Bogor. 